\title{
A Hybrid Approach in Design of Building Energy Management System with Smart Readiness Indicator and Building as a Service Concept
}

\author{
Andrzej Ożadowicz (D)
}

check for updates

Citation: Ożadowicz, A. A Hybrid Approach in Design of Building Energy Management System with Smart Readiness Indicator and Building as a Service Concept. Energies 2022, 15, 1432. https:// doi.org/10.3390/en15041432

Academic Editor: Luisa F. Cabeza

Received: 14 January 2022

Accepted: 14 February 2022

Published: 16 February 2022

Publisher's Note: MDPI stays neutral with regard to jurisdictional claims in published maps and institutional affiliations.

Copyright: (c) 2022 by the author. Licensee MDPI, Basel, Switzerland. This article is an open access article distributed under the terms and conditions of the Creative Commons Attribution (CC BY) license (https:/ / creativecommons.org/licenses/by/ $4.0 /)$.
Department of Power Electronics and Energy Control Systems, Faculty of Electrical Engineering, Automatics, Computer Science and Biomedical Engineering, AGH University of Science and Technology, al. Mickiewicza 30, 30-059 Krakow, Poland; ozadow@agh.edu.pl; Tel.: +48-12-617-50-11

\begin{abstract}
Improving energy efficiency and increasing the level of intelligence are two main factors determining the current development trends for new and modernized buildings. They are especially important in the perspective of development of prosumer installations and local microgrids. A key tool to achieve these goals is a well-designed and implemented Building Automation and Control System (BACS). This paper presents a new hybrid approach to the design and technical organization of BACS based on the provisions of the EN 15232 standard and the guidelines of the Smart Readiness Indicator (SRI) defined in the Energy Performance of Buildings Directive 2018 (EPBD 2018). The main assumptions of this hybrid approach along with examples of functional BACS designs for small prosumer installations organized according to them are provided. Potential impact on building energy performance is discussed as well. Finally, a SWOT analysis of the possibility of merging the EN 15232 standard guidelines and the SRI assessment methodology to develop uniform technical guidelines for the BACS functions design and evaluation of their impact on the buildings' energy efficiency are discussed.
\end{abstract}

Keywords: building energy management systems; building automation and control systems; smart readiness indicator; building as a service; EN 15232 standard; prosumer

\section{Introduction}

The development of Renewable Energy Sources (RES) technologies for heating and electricity causes a systematic growth of the market and commercial offer in the field of new RES solutions dedicated to applications within building infrastructure. In addition, an increasing number of buildings is being equipped with control and monitoring systems for various devices and subsystems of their infrastructure, such as heating, ventilation, and air conditioning systems (HVAC), lighting and electrical power as well as domestic hot water (DHW) supply systems. As a result, buildings and building complexes along with distributed RES can form local prosumer microgrids [1-3]. This development trend requires both legislative and technical support for organizing energy management systems and improving the energy efficiency of the buildings themselves and the accompanying infrastructure.

In the European Union, the basic documents regulating these issues are the Energy Performance of Buildings Directive (EPBD) [4] and the Energy Efficiency Directive [5]. The first revision of the EPBD in 2010 [4] introduces technical building systems as well as active control systems such as automation and monitoring systems aiming to control, manage and save energy (Article 8 of the Directive). As a reference, the EN 15232 standard was published in 2012 providing guidance on the selection of functions for building automation and control systems (BACS) and technical building management (TBM). The revised version of the EN 15232 standard from 2017 is now in force [6], and its guidelines allow automation engineers and integrators to select proper functions of the BACS implemented 
within building management system (BMS) and estimate and assess their impact on energy efficiency improvement in buildings. However, they apply only to a few categories of building infrastructure equipment: (i) heating, (ii) domestic hot water supply, (iii) cooling, (iv) ventilation and air conditioning, (v) lighting and (vi) blinds defined in the standard. The standard lacks any categorization or guidance on control and monitoring functions related to the aforementioned RES infrastructure integration and operation [3,7].

In 2018, the EPBD directive was revised (EPBD 2018) [8], considering how the provisions and guidelines of the previous version of the directive from 2010 were implemented by EU Member States, what elements proved successful, which require improvement, additional or even new actions. In addition to the previously mentioned BACS and TBM, in this revised EPBD 2018, new technologies related to smart grids, smart buildings, homes and electromobility have been introduced as well. Above all, a new instrument-Smart Readiness Indicator (SRI) was introduced. According to its definition, the SRI "should be used to measure the capacity of buildings to use information and communication technologies and electronic systems to adapt the operation of buildings to the needs of the occupants and the grid and to improve the energy efficiency and overall performance of buildings. The smart readiness indicator should raise awareness amongst building owners and occupants of the value behind building automation and electronic monitoring of technical building systems and should give confidence to occupants about the actual savings of those new enhanced functionalities" [8,9]. This definition opens new ways for implementation of the BACS and TBM functions, discussed in the EN 15232 standard, in smart buildings to support new smart energy meters and power supply parameters analyzers as well as controllers for local RES, energy storage and converters integrated within the building infrastructure. Additional requirements and guidelines related to this equipment are provided in an overview of the smart ready services and their functionality levels within the final report on the development of SRI, prepared by a special technical team for the European Commission [10]. There are services/functions dedicated to the organization of building energy management systems (BEMS), demand side management (DSM) with demand side response (DSR) and support for building integration within the smart grid (SG) proposed in this report. They could be considered as a supplement to the above-mentioned lacks/gaps in the guidelines for BACS and TBM in the EN 15233 standard, and this question will be discussed in this paper.

The EPBD 2018 states that digitalization of the energy system is quickly changing the energy landscape, from the simple integration of RES to advanced SG and smart buildings integrated within SG. Therefore, the digitalization of the building sector is needed with deployment of high-capacity information and communication technologies (ICT) networks as well as building automation field-level networks for direct machine-to-machine (M2M) data communication. In this context, a Building as a Service (BaaS) platform, supported by Internet of Things paradigm and ICT technologies has been proposed [11-13]. These tools provide the technical possibilities of organizing data acquisition systems from various in- and out-of-building sources along with the integration of data analytics services in the cloud and/or locally in automation servers, distributed controllers, etc. Moreover, the use of universal tags (like Haystack [14]) in the description of data/network variables along with development of advanced event-based device control scenarios with the BACS and TBM integrated in open, distributed field-level networks supports efforts to build energy performance improvements [11,15].

\subsection{Related Work-State of the Art}

Selection, verification, and development of the BACS and TBM supporting building energy performance and energy efficiency improvements have been discussed for the last two decades by several research and engineer teams all over the world. There are two study fields considered and shortly presented in this part of the paper.

The levels of the BACS and TBM impact on energy efficiency provided in the EN 15232 were mostly based on the results delivered from a large set of simulation runs, conducted 
with the TRNSYS tool [3,6], and need to be verified in real applications. In [16,17], Beccali et al. proposed validation methods to evaluate effects of BACS and TBM on lighting. The results provided and discussed there showed that the calculated, real BACS factors' values for different BACS efficiency classes from the EN 15232 standard are quite close to the theoretical values. Moreover, the authors concluded that the results are closely related to many physical, technical, and human factors influencing the functioning of the analyzed buildings, their individual rooms, zones, etc. This paper points to the importance of external conditions (season, weather) and recommends analyzing the levels of energy efficiency improvement in buildings at least throughout the year. Therefore, case studies and research for specific types of buildings, located in different countries and climatic zones, are so important. The BACS and TBM selection considering building retrofitting actions with energy efficiency improvements should be analyzed as well. Therefore, in [18,19], Felius et al. investigate the BACS impact on energy efficiency for two popular kinds of residential buildings in cold climate countries. They analyzed different BACS efficiency classes not only from their energy performance impact on buildings point of view but as guidelines for the selection of control functions. The results show significant potential for cost-effective thermal energy savings-about $25 \%$ for apartments and even $57 \%$ for the single-family house, with combination of the BACS and other retrofitting measures in buildings. Furthermore, large capabilities in optimizing the energy performance of different systems in buildings with appropriately selected BACS and TBM functions have been investigated by Engvang et al. in [20]. The authors state that EN 15232 standard with the BACS efficiency classes could and should be used not only for building automation design for new and retrofitted buildings but to assess and evaluate the current status of their BACS and BMS and identify potential improvements as well. In the paper, they present results of assessment and evaluation in Danish buildings achieved with implementation of the eu.bac System methodology in a university office building, complying with the lowest automation and control class D. Two BACS retrofit packages analyzed giving energy savings up to $28.5 \%$.

The author of this paper provided results of their own observations and research related to evaluation of the BACS impact on energy performance for lights in buildings [21] and streetlights [22] considered as crucial parts of building as well as building campuses infrastructure. This kind of research opens a way for discussion about the role of BASC and TBM functions in building energy efficiency improvements, especially bearing in mind new devices, subsystems in building infrastructure related to the RES, local microgrids, smart metering, electric vehicles, etc. This role is very significant, important, and it has been underlined in the EPBD 2018 directive provisions with the SRI introduction. However, the discussion continued, and during the last three years the SRI with its guidelines became an additional element. In review paper [23], the SRI is considered and compared to other existing Key Performance Indicators of buildings, in the context of the need to upgrade the retrofitting strategies into Smart ones, to be able to respond to external dynamic changes and challenges (weather conditions, RES and smart grid development with prosumers, etc.) in building use. Currently, one of the research paths on the SRI indicator focuses on evaluating how this indicator with its guidelines presented in report [10] could affect the energy performance of buildings. In [24] Fokaides et al. discusses this question, giving some results of using the SRI in assessment procedures, for example, in a building at Frederic University in Cyprus. Results for smartness of the building equipped with BMS were quite high (total SRI score: 52\%); however, the energy class for that building, according to energy performance certificate is $\mathrm{D}$ (quite low). Some information related to the energy consumption in the budling analyzed has been provided together with a discussion about the SRI integration into energy performance certificates and advanced building automation systems, functions and services. Moreover, gaps and lacks within the SRI guidelines and assessment methodology have been briefly discussed. On the other hand, Märzinger et al. $[25,26]$ propose extending the application of the SRI to the energy monitoring and management areas, providing additional method and tools for using SRI guidelines in 
SG, DSM and DSR design in buildings and local microgrids. Relations between the SRI guidelines and BACS with TBM applications oriented to energy efficiency improvements are investigated in [20]. Engvang et al. present case studies for evaluation of energy performance in Danish buildings using the emerging and most comprehensive energy certification scheme-the eu.bac system audit [27]. This is an evaluation and auditing methodology relying on the EN 15232 standard as well as dealing with all the specifications and aspects of the BACS selection. However, the authors discuss usefulness of the SRI methodology allowing a wider range and a broader context of investigation considering additional impact criteria with impact on the energy efficiency. They suggest the potential of using the SRI guidelines not only in evaluating the smartness of buildings but also in analyzing the impact of the BACS structure and design on buildings energy performance. Last but not least, in [28], Engelsgraad et al. propose an interactive tool for BACS auditingIBACSA. This tool integrates both EN 15232 standard and SRI methodology to assess BACS impact on building energy efficiency as well as to buildings smartness evaluation, using a qualitative-based multi-criteria approach. Moreover, it could serve as a user-friendly and comprehensive platform for effective design of the BACS both in new and retrofitted buildings, considering the level of smartness and energy efficiency improvements.

\subsection{Contributions}

Bearing in mind all the issues and challenges discussed above, in this paper, the author proposes a novel hybrid approach to the design and technical organization of field-level BACS networks, with functions supporting the implementation of active DSM/DSR and BEMS. Therefore, the author discusses provisions and guidelines proposed in the EN 15232 standard, the SRI development report as well as BaaS project report, gathering those that should be used in the RES service systems and DSM with BEMS in local building prosumer microgrids. The main contributions of this work are given as follows:

1. Design assumptions proposed by the author for a small prosumer installation (in a residential house or a small public/commercial building), with categories of devices as well as BACS and utility functions.

2. The paper presents an original set of control functions for photovoltaic (PV) systems within the prosumer installation/microgrid, with proposed, possible assignment to the BACS efficiency classes defined in the EN 15232. It is the author's original, new proposal to amend/supplement/revision of the EN 15232 standard provisions, considering new devices and functions to control PV panels and effectively manage the energy they produce.

3. Functional designs of the BACS for small prosumer microgrid in residential house or small commercial, public buildings, based on the EN 15232 standard guidelines as well as the SRI services and presented in accordance with the convention adopted in the VDI 3813 standard [29].

4. Strengths, Weaknesses, Opportunities and Threats (SWOT) analysis of proposed new hybrid approach to the design of the BACS and integrated, interpenetrating development of the SRI as well as EN 15232 provisions with guidelines for new, extended BACS and SRI impact on building energy performance.

The rest of the paper is organized as follows: Section 2 provides materials and methods based on related work discussed in Section 1 with original concept of BACS control functions for PV panels proposed by the author in accordance with the convention adopted in the EN 15232 standard. In Section 3 functional designs of control and energy management systems for small prosumer installation are presented with evaluation of their potential impact on building energy performance. Section 4 gives short results discussion and SWOT analysis related to integrated SRI and EN 15232 guidelines development. Section 5 provides the conclusions and future works. Table 1 lists the acronyms and abbreviations used in this paper. 
Table 1. Abbreviations and acronyms used within the paper (alphabetical order).

\begin{tabular}{cl}
\hline $\begin{array}{c}\text { Abbreviation } \\
\text { Acronym }\end{array}$ & \\
\hline BACS & Building Automation and Control System \\
SRI & Smart Readiness Indicator \\
AC & Alternating Current \\
B2G & Building to Grid \\
BaaS & Building as a Service \\
BEMS & Building Energy Management System \\
BMS & Building Management System \\
DC & Direct Current \\
DHW & Domestic Hot Water \\
DSM & Demand Side Management \\
DSR & Demand Side Response \\
EPBD & Energy Performance of Buildings Directive \\
HVAC & Heating, Ventilation, and Air Conditioning \\
ICT & Information and Communication Technologies \\
M2M & Machine-to-Machine \\
PV & Photovoltaic \\
RES & Renewable Energy Sources \\
SG & Smart Grid \\
SOC & State of Charge \\
SWOT & Strengths, Weaknesses, Opportunities and Threats (analysis) \\
TBM & Technical Building Management \\
TBS & Technical Building Systems \\
\hline
\end{tabular}

\section{Methods and Tools}

One of the most important elements of planning the concept and design of a BEMS for a specific building, in particular with prosumer installations, is the selection of control and monitoring functions for the operation of building infrastructure devices and possible local microgrid. In practice, such a selection is very often subjective and depends on the level of knowledge and experience of the building automation engineers, integrators responsible for the implementation of the BACS or BMS solutions. Therefore, mentioned previously the EN 15232 standard, standardize the categories of building automation functions for specific groups of devices and systems of building infrastructure, along with guidelines for their organization, possible integration and, as a result, the impact on the energy efficiency of the building $[7,27,30]$. However, the EN 15232 standard does not define any energy control and management functions in relation to new infrastructure of prosumer buildings, such as RES controllers, energy storage, energy conversion systems and others. In this regard, the guidelines for selecting the functions of BACS are limited and focus primarily on controlling the operation of electric loads and heaters, HVAC systems, additionally integrating signals from various sensors of parameters related to the functioning of buildings, such as temperature, $\mathrm{CO}_{2}$ level, presence of people in the rooms, the level of intensity of daylight and artificial light, etc.

\subsection{Infrastructure and Fuctions for Small Prosumer Installations-Proposition in Context of BACS Development}

Märzinger T. and Österreicher D. in [26] indicate the need to include these aforementioned elements of the prosumer installation. They propose a methodology for designing energy management systems for a local microgrid on a district scale and point to several important functions that could and should provide control and building automation systems. Among them, it is worth to mention control engineering across buildings, efficient use and control of RES, load management optimization for district, connection to e-mobility, large scale storage implementation, interaction of the building with the grid infrastructure (Building to Grid-B2G), etc. Considering these challenges and technical needs of systems supporting the operation of RES and DSM/DSR mechanisms for energy 
efficient prosumer microgrids with smart building technologies discussed by the author in [3], Table 2 proposes original design assumptions for a building automation system for a prosumer installation in a residential building. The author takes into account several the most important systems (photovoltaic panels, heat pumps, DC and AC receivers) in prosumer microgrid, considering devices and functions supporting the operation of this infrastructure. Moreover, the assumptions consider the use of energy generated by PV panels to power devices of the building automation itself. This is an important issue that is seldom addressed in the design of system installations and energy balances of buildings equipped with BACS and/or BMS [31,32].

Table 2. Set of design assumptions for the BACS devices and utility as well as automation functions for a small prosumer installation (the original author's proposition).

\begin{tabular}{|c|c|c|}
\hline System & Devices & Functions \\
\hline PV solar panels & $\begin{array}{l}\text { Air temperature sensor } \\
\text { Sunlight sensor-daylight intensity } \\
\text { Temperature sensor for solar panels } \\
\text { Anemometer (wind speed measurement) } \\
\text { Battery charging regulator } \\
\text { Inverter } \\
\text { Maximum Power Point (MPP) tracker-A } \\
\text { follow module to maintain the maximum } \\
\text { power of the panels }\end{array}$ & $\begin{array}{l}\text { Weather station for a PV installation } \\
\text { Control of the PV panels position of panels in } \\
\text { the case of MPP tracker use } \\
\text { Monitoring the influence of temperature on the } \\
\text { performance of the PV panels } \\
\text { Controlling the position of the panels parallel } \\
\text { to the ground/roof surface (protection against } \\
\text { the strong winds) }\end{array}$ \\
\hline Heat pumps & $\begin{array}{l}\text { Air temperature sensor } \\
\text { Water temperature sensor } \\
\text { Occupancy sensor } \\
\text { Heat pump power controller }\end{array}$ & $\begin{array}{l}\text { Space/room heating in buildings } \\
\text { Heating of DHW } \\
\text { Temperature control in the DHW tank with } \\
\text { integrated electric heating } \\
\text { Starting the storage tank charging time } \\
\text { according to the time schedule } \\
\text { Control of the heat pump source, taking into } \\
\text { account the priorities of the BMS system and } \\
\text { user settings }\end{array}$ \\
\hline DC loads-direct current & $\begin{array}{l}\text { Electric vehicle charging stations } \\
\text { Storage tanks-batteries } \\
\text { Electric heater-heating water in the tank } \\
\text { (boiler) } \\
\text { BACS controllers } \\
\text { BACS and BMS modules } \\
\text { Automation servers }\end{array}$ & $\begin{array}{l}\text { Use of electricity from solar panels to charge } \\
\text { batteries in electric vehicles } \\
\text { Controlling the DC loads in accordance with } \\
\text { the time schedule, BACS operating mode } \\
\text { Collecting/harvesting electricity in the event of } \\
\text { excess production from PV panels } \\
\text { Power supply to the most important loads in } \\
\text { the building in the event of a power failure } \\
\text { Use of electricity from the solar panels to } \\
\text { heat water } \\
\text { Use of electricity from solar panels to power } \\
\text { the BACS system modules }\end{array}$ \\
\hline AC loads-alternating current & $\begin{array}{l}\text { Electric loads in the building } \\
\text { Controlled relays (circuits) } \\
\text { Smart power sockets, lighting } \\
\text { Audio-video equipment } \\
\text { Household appliances } \\
\text { Inverter-DC to AC converter } \\
\text { Occupancy sensors } \\
\text { Automation servers }\end{array}$ & $\begin{array}{l}\text { Controlling the work of AC loads } \\
\text { Supplying AC loads with energy from the DC } \\
\text { power system after conversion } \\
\text { Controlling the AC loads in accordance with } \\
\text { the time schedule, BACS operating mode }\end{array}$ \\
\hline
\end{tabular}

2.2. Control and Monitoring Strategy for Prosumer Installations-Functional Analysis in Context of the SRI Development and Guidelines

As mentioned in Section 1, the EPBD 2018 along with SRI development report provided advanced tools to evaluate smart readiness level of the buildings. According to the EPBD 
2018, this evaluation should be based on three key functionalities relating to the building and its technical building systems [8]:

- The ability to maintain energy performance and operation of the building through the adaptation of energy consumption for example through use of energy from renewable sources,

- The ability to adapt its operation mode in response to the needs of the occupant while paying due attention to the availability of user-friendliness, maintaining healthy indoor climate conditions and the ability to report on energy use,

- The flexibility of a building's overall electricity demand, including its ability to enable participation in active and passive as well as implicit and explicit demand response, in relation to the grid, for example through flexibility and load shifting capacities.

Provisions of the EPBD 2018 indicate the most important technologies, technical solutions and services to improve the SRI index, such as smart meters, BACS, self-regulating devices for regulating the room temperature, built-in household appliances, electric vehicle charging points, energy storage and RES, including control functions and the interoperability of these elements. Gathering all these assumptions, the SRI development report provides detailed catalogues of services/control, monitoring functions, with several functionality levels (similar to BACS efficiency classes) and three SRI assessment methods [10]: (i) Method A-A simplified quick scan, focusing mainly on residential buildings and small nonresidential buildings, (ii) Method B-A detailed assessment, dedicated to non-residential buildings (commercial, public utility, office, etc.) and (iii) Method C-A metered/measured method, based on measurements of equipment operation parameters and energy consumption, carried out on the existing, operated building over a longer period of time. Since the catalogs of services/functions differ according to the assessment method, for this article, the catalog for method A (residential and small public buildings) has been selected. Within this catalog, there are several domains of services/functions related to different kinds of buildings' infrastructure subsystems: heating, DHW, cooling, controlled ventilation, lighting, dynamic building envelope, electricity, electric vehicle charging, monitoring and control [10]. Most of them are directly connected with categories of subsystems and BACS control functions proposed in the EN 15232 standard. Therefore, the control functions from the EN 15232 standard could be compared, related to the catalogue of services from the SRI development report and finally considered in the light of both documents. For this comparison, a set of selected services related to prosumers' installations and especially to the RES and PV panels integration within the BACS control and BEMS energy management systems is presented in Table 3. The services/functions that specifically support the implementation of active energy management with DSM/DSR mechanisms are marked in green.

As seen in Table 3, there are several crucial and relevant services/functions identified for the SRI level assessment process. However, they could be useful not only to assess a smart readiness (smartness) of buildings but also in the design of buildings and their TBS/TBM with BACS control and monitoring functions.

Therefore, according to the author, the services gathered in Table 3 could be treated as input material for introducing changes and new additions to sets of BACS and TBM functions provided within the EN15232 standard. This is a key assumption of a new hybrid approach in design of BMS, in particular BEMS and would help automation engineers and integrators to select functions that could be implemented within BMS and BEMS, supporting active energy management in buildings in the context of RES handling, energy storage and vehicle charging stations. Moreover, after conducting a series of tests, simulations and case-study observations, additional, modified BACS efficiency factors should be determined for that standard $[6,7,33]$. This would allow the estimation of the impact of active energy management functions with DSM/DSR mechanisms on the energy efficiency improvements of buildings and not only the estimation of their SRI level. 
Table 3. Selected services/functions from the catalogue of services provided by the SRI development report for simplified assessment method A and directly related to prosumers' installations in residential houses and small public, commercial buildings [10].

\begin{tabular}{|c|c|c|c|c|c|c|}
\hline Domain & $\begin{array}{c}\text { Smart Ready } \\
\text { Service }\end{array}$ & $\begin{array}{l}\text { Functionality Level } 0 \\
\text { (as Non-smart Default) }\end{array}$ & $\begin{array}{c}\text { Functionality Level } \\
1\end{array}$ & $\begin{array}{l}\text { Functionality Level } \\
2\end{array}$ & $\begin{array}{c}\text { Functionality Level } \\
3 \\
\end{array}$ & $\begin{array}{c}\text { Functionality Level } \\
4\end{array}$ \\
\hline $\begin{array}{l}\text { Domestic } \\
\text { hot water }\end{array}$ & $\begin{array}{l}\text { Control of DHW } \\
\text { storage charging }\end{array}$ & None & $\begin{array}{l}\text { HW storage vessels } \\
\text { available }\end{array}$ & $\begin{array}{l}\text { Automatic charging } \\
\text { control based on } \\
\text { local availability of } \\
\text { renewables or } \\
\text { information from } \\
\text { electricity grid } \\
\text { (DSR, DSM) }\end{array}$ & - & - \\
\hline \multirow[t]{2}{*}{ Cooling } & $\begin{array}{l}\text { Generator control } \\
\text { for cooling } \\
\text { production }\end{array}$ & $\begin{array}{l}\text { On/off control of } \\
\text { cooling production }\end{array}$ & $\begin{array}{l}\text { Multi-stage control } \\
\text { of cooling } \\
\text { production capacity } \\
\text { depending on the } \\
\text { load or demand } \\
\text { (e.g., on/off of } \\
\text { several } \\
\text { compressors) }\end{array}$ & $\begin{array}{l}\text { Variable control of } \\
\text { cooling production } \\
\text { capacity depending } \\
\text { on the load or } \\
\text { demand (e.g., hot } \\
\text { gas bypass, inverter } \\
\text { frequency control) }\end{array}$ & $\begin{array}{l}\text { Variable control of } \\
\text { cooling production } \\
\text { capacity depending } \\
\text { on the load and } \\
\text { external signals } \\
\text { from grid }\end{array}$ & - \\
\hline & $\begin{array}{l}\text { Flexibility and grid } \\
\text { interaction }\end{array}$ & No automatic control & $\begin{array}{l}\text { Scheduled } \\
\text { operation of cooling } \\
\text { system }\end{array}$ & $\begin{array}{l}\text { Self-learning } \\
\text { optimal control of } \\
\text { cooling system }\end{array}$ & $\begin{array}{l}\text { Cooling system } \\
\text { capable of flexible } \\
\text { control through grid } \\
\text { signals (e.g., DSM) }\end{array}$ & $\begin{array}{l}\text { Optimized control } \\
\text { of cooling system } \\
\text { based on local } \\
\text { predictions and grid } \\
\text { signals (e.g., } \\
\text { through model } \\
\text { predictive control) }\end{array}$ \\
\hline \multirow{4}{*}{ Electricity } & $\begin{array}{l}\text { Storage of locally } \\
\text { generated electricity }\end{array}$ & None & $\begin{array}{l}\text { On site storage of } \\
\text { electricity (e.g., } \\
\text { electric battery) }\end{array}$ & $\begin{array}{l}\text { On site storage of } \\
\text { energy (e.g., electric } \\
\text { battery or thermal } \\
\text { storage) with } \\
\text { controller based on } \\
\text { grid signals }\end{array}$ & $\begin{array}{l}\text { On site storage of } \\
\text { energy (e.g., electric } \\
\text { battery or thermal } \\
\text { storage) with } \\
\text { controller } \\
\text { optimizing the use } \\
\text { of locally generated } \\
\text { electricity }\end{array}$ & $\begin{array}{l}\text { On site storage of } \\
\text { energy (e.g., electric } \\
\text { battery or thermal } \\
\text { storage) with } \\
\text { controller } \\
\text { optimizing the use } \\
\text { of locally generated } \\
\text { electricity and } \\
\text { possibility to } \\
\text { feedback into the } \\
\text { grid }\end{array}$ \\
\hline & $\begin{array}{l}\text { Reporting } \\
\text { information } \\
\text { regarding electricity } \\
\text { consumption }\end{array}$ & None & $\begin{array}{l}\text { Reporting on } \\
\text { current electricity } \\
\text { consumption on } \\
\text { building level }\end{array}$ & $\begin{array}{l}\text { Real-time feedback } \\
\text { or benchmarking on } \\
\text { building level }\end{array}$ & $\begin{array}{l}\text { Real-time feedback } \\
\text { or benchmarking on } \\
\text { appliance level }\end{array}$ & $\begin{array}{l}\text { Real-time feedback } \\
\text { or benchmarking on } \\
\text { appliance level with } \\
\text { automated } \\
\text { personalized } \\
\text { recommendations }\end{array}$ \\
\hline & $\begin{array}{l}\text { Reporting } \\
\text { information } \\
\text { regarding local } \\
\text { electricity } \\
\text { generation }\end{array}$ & None & $\begin{array}{l}\text { Current generation } \\
\text { data available }\end{array}$ & $\begin{array}{l}\text { Actual values and } \\
\text { historical data }\end{array}$ & $\begin{array}{l}\text { Performance } \\
\text { evaluation } \\
\text { including } \\
\text { forecasting and/or } \\
\text { benchmarking }\end{array}$ & $\begin{array}{l}\text { Performance } \\
\text { evaluation } \\
\text { including } \\
\text { forecasting and/or } \\
\text { benchmarking also } \\
\text { including predictive } \\
\text { management and } \\
\text { fault detection }\end{array}$ \\
\hline & $\begin{array}{l}\text { Reporting } \\
\text { information } \\
\text { regarding energy } \\
\text { storage }\end{array}$ & None & $\begin{array}{l}\text { Current state of } \\
\text { charge (SOC) data } \\
\text { available }\end{array}$ & $\begin{array}{l}\text { Actual values and } \\
\text { historical data }\end{array}$ & $\begin{array}{l}\text { Performance } \\
\text { evaluation } \\
\text { including } \\
\text { forecasting and/or } \\
\text { benchmarking }\end{array}$ & $\begin{array}{l}\text { Performance } \\
\text { evaluation } \\
\text { including } \\
\text { forecasting and/or } \\
\text { benchmarking also } \\
\text { including predictive } \\
\text { management and } \\
\text { fault detection }\end{array}$ \\
\hline $\begin{array}{l}\text { Electric vehicle } \\
\text { charging }\end{array}$ & $\begin{array}{l}\text { EV Charging Grid } \\
\text { balancing }\end{array}$ & $\begin{array}{l}\text { Not present } \\
\text { (uncontrolled charging) }\end{array}$ & $\begin{array}{l}\text { 1-way controlled } \\
\text { charging (e.g., } \\
\text { including desired } \\
\text { departure time and } \\
\text { grid signals for } \\
\text { optimization) }\end{array}$ & $\begin{array}{l}\text { 2-way controlled } \\
\text { charging (e.g., } \\
\text { including desired } \\
\text { departure time and } \\
\text { grid signals for } \\
\text { optimization) }\end{array}$ & - & - \\
\hline
\end{tabular}


Table 3. Cont.

\begin{tabular}{|c|c|c|c|c|c|c|}
\hline Domain & $\begin{array}{l}\text { Smart Ready } \\
\text { Service }\end{array}$ & $\begin{array}{l}\text { Functionality Level } 0 \\
\text { (as Non-smart Default) }\end{array}$ & $\underset{1}{\text { Functionality Level }}$ & $\begin{array}{l}\text { Functionality Level } \\
2\end{array}$ & $\begin{array}{c}\text { Functionality Level } \\
3\end{array}$ & $\begin{array}{c}\text { Functionality Level } \\
4\end{array}$ \\
\hline \multirow{3}{*}{$\begin{array}{l}\text { Monitoring } \\
\text { and control }\end{array}$} & $\begin{array}{l}\text { Single platform that } \\
\text { allows automated } \\
\text { control and } \\
\text { coordination } \\
\text { between TBS * + } \\
\text { optimization of } \\
\text { energy flow based } \\
\text { on occupancy, } \\
\text { weather and grid } \\
\text { signals }\end{array}$ & None & $\begin{array}{l}\text { Single platform that } \\
\text { allows manual } \\
\text { control of multiple } \\
\text { TBS }\end{array}$ & $\begin{array}{l}\text { Single platform that } \\
\text { allows automated } \\
\text { control and } \\
\text { coordination } \\
\text { between TBS }\end{array}$ & $\begin{array}{l}\text { Single platform that } \\
\text { allows automated } \\
\text { control and } \\
\text { coordination } \\
\text { between TBS + } \\
\text { optimization of } \\
\text { energy flow based } \\
\text { on occupancy, } \\
\text { weather and grid } \\
\text { signals }\end{array}$ & - \\
\hline & $\begin{array}{l}\text { Smart Grid } \\
\text { integration }\end{array}$ & $\begin{array}{l}\text { None-no harmonization } \\
\text { between grid and TBS; } \\
\text { building is operated } \\
\text { independently from the } \\
\text { grid load }\end{array}$ & $\begin{array}{l}\text { Demand side } \\
\text { management } \\
\text { possible for (some) } \\
\text { individual TBS, but } \\
\text { not coordinated } \\
\text { over various } \\
\text { domains }\end{array}$ & $\begin{array}{l}\text { Coordinated } \\
\text { demand side } \\
\text { management of } \\
\text { multiple TBS }\end{array}$ & - & - \\
\hline & $\begin{array}{l}\text { Central reporting of } \\
\text { TBS performance } \\
\text { and energy use }\end{array}$ & None & $\begin{array}{l}\text { Central or emote } \\
\text { reporting of } \\
\text { real-time energy use } \\
\text { per energy carrier }\end{array}$ & $\begin{array}{l}\text { Central or remote } \\
\text { reporting of } \\
\text { real-time energy use } \\
\text { per energy carrier, } \\
\text { combining TBS of at } \\
\text { least } 2 \text { domains in } \\
\text { one interface }\end{array}$ & $\begin{array}{l}\text { Central or remote } \\
\text { reporting of } \\
\text { real-time energy use } \\
\text { per energy carrier, } \\
\text { combining TBS of } \\
\text { all domains } \\
\text { in one interface }\end{array}$ & - \\
\hline
\end{tabular}

* TBS-Technical Building Systems defined in the EBPD [4] as a set of system requirements in respect of the overall energy performance, the proper installation, and the appropriate dimensioning, adjustment and control of the technical building systems which are installed in existing buildings.

\subsection{A New Set of BACS Fuctions for Prosumer Installations-Proposition in Context of the EN 15232 Standard}

The EN 15232 standard collects and categorizes BACS and TBM functions that can affect the energy performance of buildings. There are four different BACS efficiency classes provided: (i) the lowest Class D: Non-energy efficient BACS, (ii) Class C: Standard BACS, (iii) Class B: Advanced BACS and TBM systems and the highest one (iv) Class A: High energy performance BACS and TBM systems. The classes are considered both for residential and non-residential buildings. As mentioned before in Section 1, control function list and assignment to BACS efficiency classes for heat pumps, DHW supply system and electric loads device categories are directly defined in the EN 15232 standard $[6,7,33]$. The main rule to achieve higher/better BACS efficiency class is to select and implement more integrated control for generation and emission of the heat and DHW in building, with individual and active control of the rooms' temperature, lighting level, air quality, etc.

Based on this knowledge and on the principles adopted in the EN 15232 standard, this paper proposes original set of BACS control functions for PV systems for prosumer installation in residential houses and small public or commercial buildings. Proposition of an assignment to the BACS efficiency classes defined in the EN 15232 standard is depicted as well and presented in Table 4.

The control functions proposed and classified in Table 4 have not been implemented and verified yet. They should be considered as a voice in the discussion of changes, possible new provisions in standards, technical guidelines, etc.

All the control functions and services depicted in Tables 3 and 4 are considered as guidelines for building a strategy for controlling and monitoring the operation of devices under TBS for the previously adopted design assumptions of a small prosumer installation proposed in Table 2. Functional design for such an installation, considering the implementation of BACS based on open building automation standards (LonWorks, KNX, BACnet) and the Internet of Things modules, is described and presented in the next section. 
Table 4. Control function list of PV solar systems and possible assignment to BACS efficiency classes (the original author's proposition).

\begin{tabular}{|c|c|c|c|c|c|c|c|c|c|c|}
\hline & & & \multicolumn{8}{|c|}{ Definition of Classes } \\
\hline & & & \multicolumn{4}{|c|}{ Residential } & \multicolumn{4}{|c|}{ Non-Residential } \\
\hline \multicolumn{3}{|c|}{ PV SOLAR SYSTEM CONTROL AND MANAGEMENT } & $\mathbf{D}$ & C & B & A & D & $\mathrm{C}$ & B & A \\
\hline \multirow[t]{4}{*}{1} & $\begin{array}{l}\text { PV PAN } \\
\text { The ava }\end{array}$ & $\begin{array}{l}\text { SITION CONTROL } \\
\text { y of functions depends on the method of installation and assembly of }\end{array}$ & PV & & & & & & & \\
\hline & 0 & No automatic control & & & & & & & & \\
\hline & 1 & $\begin{array}{l}\text { Automatic control of the PV panel position } \\
\text { Automatic control of the PV panel position with use of the system }\end{array}$ & & & & & & & & \\
\hline & 2 & $\begin{array}{l}\text { following the position of the Sun in connection with the } \\
\text { weather station }\end{array}$ & & & & & & & & \\
\hline \multirow[t]{3}{*}{2} & $\begin{array}{l}\text { DOMES } \\
\text { Heating }\end{array}$ & $\begin{array}{l}\text { EAT WATER HEATING CONTROL } \\
\text { with electricity from PV panels }\end{array}$ & & & & & & & & \\
\hline & $\begin{array}{ll}0 \\
1\end{array}$ & $\begin{array}{l}\text { No automatic control } \\
\text { Automatic control on/off with variable heating time }\end{array}$ & & & & & & & & \\
\hline & 2 & $\begin{array}{l}\text { Automatic control on/off with variable heating time and } \\
\text { temperature management based on signals from several sensors }\end{array}$ & & & & & & & & \\
\hline \multirow[t]{4}{*}{3} & POWER & TROL OF ELECTRIC VEHICLE CHARGING STATION & & & & & & & & \\
\hline & 0 & No automatic control & & & & & & & & \\
\hline & 1 & $\begin{array}{l}\text { Automatic control with a fixed time program/schedule } \\
\text { to reduce the charging station working time }\end{array}$ & & & & & & & & \\
\hline & 2 & $\begin{array}{l}\text { Automatic control with an active demand prediction/management } \\
\text { to reduce the charging station working time }\end{array}$ & & & & & & & & \\
\hline \multirow[t]{4}{*}{4} & STORA & TTERIES CHARGING CONTROL & & & & & & & & \\
\hline & 0 & Automatic control on/off & & & & & & & & \\
\hline & 1 & Automatic control with a fixed time program/schedule & & & & & & & & \\
\hline & 2 & $\begin{array}{l}\text { Automatic control with an active demand prediction/management } \\
\text { and priority assessment }\end{array}$ & & & & & & & & \\
\hline \multirow[t]{4}{*}{5} & MANA & NT OF POWER FROM PV PANELS & & & & & & & & \\
\hline & 0 & Automatic control on/off & & & & & & & & \\
\hline & 1 & $\begin{array}{l}\text { Automatic control according to the time schedule of building } \\
\text { infrastructure devices operation }\end{array}$ & & & & & & & & \\
\hline & 2 & $\begin{array}{l}\text { Automatic control according to the time schedule of building } \\
\text { infrastructure devices operation with demand } \\
\text { prediction/management }\end{array}$ & & & & & & & & \\
\hline \multirow[t]{5}{*}{6} & SEQUE & CONTROL OF SEVERAL PV PANEL GROUPS & & & & & & & & \\
\hline & 0 & Time-only priorities & & & & & & & & \\
\hline & 1 & Load level-only priorities & & & & & & & & \\
\hline & 2 & Load level and demand priorities & & & & & & & & \\
\hline & 3 & $\begin{array}{l}\mathrm{PV} \text { panels efficiency priorities: individual control of } \mathrm{PV} \text { panels to } \\
\text { allow panels to operate with the highest possible efficiency }\end{array}$ & & & & & & & & \\
\hline
\end{tabular}

\section{Results}

According to the EPBD 2018 and SRI development report, utility and BACS functions are called services. It is a very universal and open concept that relates directly to the tasks performed by specific devices or groups of cooperating devices (integrated). According to it, elements of building infrastructure can be identified as tools for the provision of services, supporting the comfort of users, the safety of people and property, and the energy efficiency of the buildings themselves. Moreover, in the EPBD 2018, the SRI development report and the EN 15232 standard, there are no recommendations regarding technologies, technical solutions or BACS standards that should be used in the design and construction of automation and data communication systems for the implementation of these services/functions. This approach stays in line with the BaaS concept mentioned in Sections 1 and 2 [11,34]. Therefore, in this paper, an abstract design method described and standardized in the VDI 3813 standard [29] has been used to present functional requirements and data bindings within control and monitoring system for the previously discussed small prosumers installation. This design approach is based on a dataflow diagram that presents the information flow between atomic semantic BACS functions. The physical signals flow from sensors to actuators is shown as well. It is both technology and vendor independent and does not restrict how BACS and TBM functions are implemented [35-37]. Moreover, it is used in commercial tools for building automation designers and integrators as well [38,39]. 


\subsection{Functional Design of Control and Energy Management System for Small Prosumer Installation}

Considering the BACS functions proposed and categorized the Section 2 (Tables 3 and 4) the author proposed and designed functional diagrams along with an indication of the necessary infrastructure elements in accordance with the VDI 3813 standard, to describe the functional structure of logic functions and their links with the sensor and actuator infrastructure. For this design, the BACS and TBM functions were selected from BACS function lists provided in the EN 15232 standard for heating control and domestic hot water supply control as well as from the BACS function list of PV solar systems proposed by the author in Table 4, related to the SRI services presented in Table 3. Two organization variants of control and energy management systems for a small, local prosumer microgrid are presented in Figures 1-3, for two BACS efficiency classes C and A described in the EN 15232 standard, with additional functions proposed by the author. For the class A, the functional diagram is divided into two parts (Figures 2 and 3).

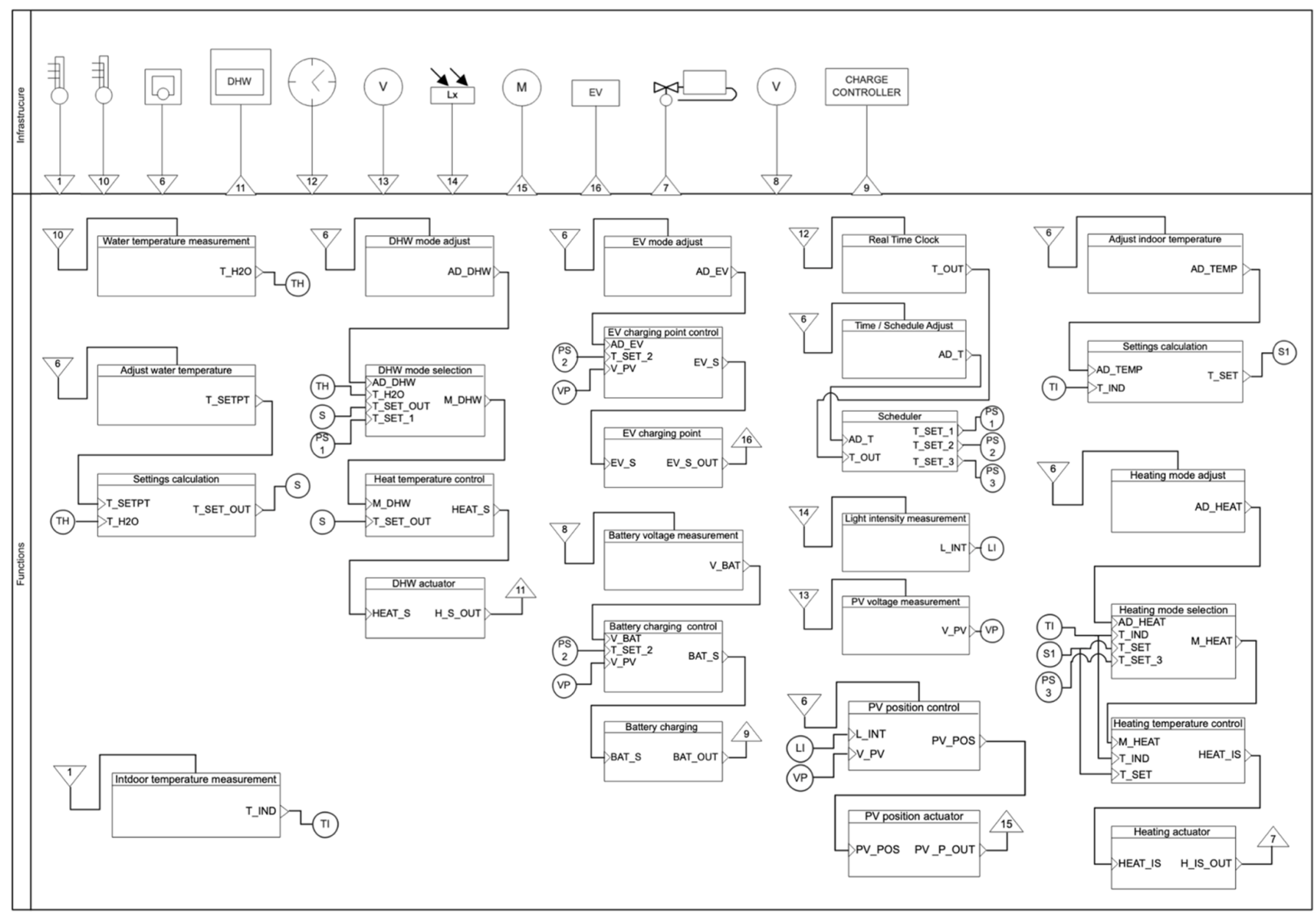

Figure 1. A functional diagram of control and energy management system for small prosumer installation organized according to the EN 15232 standard BACS efficiency class C with additional functions proposed in the paper. 


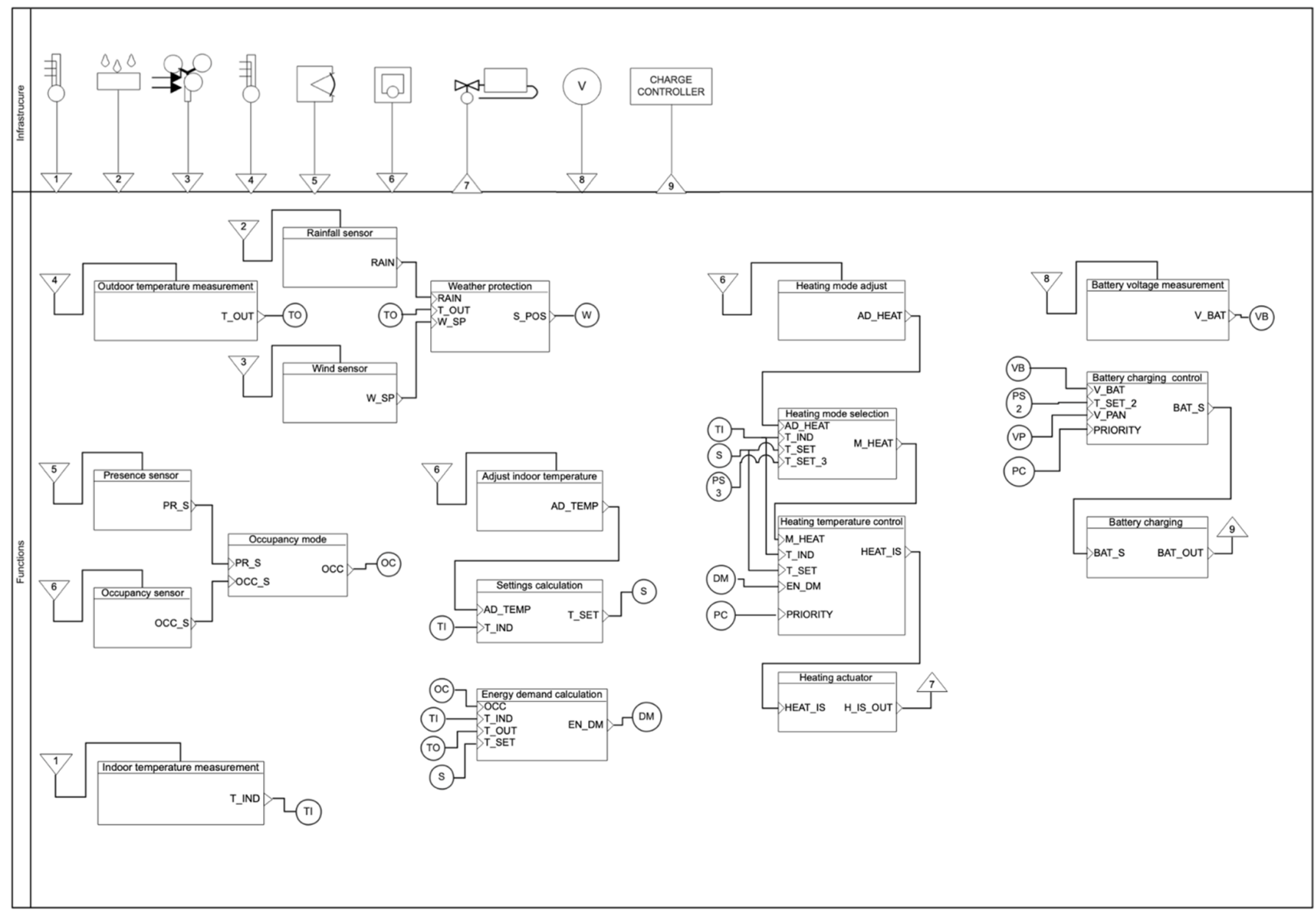

Figure 2. A functional diagram of control and energy management system for small prosumer installation organized according to the EN 15232 standard BACS efficiency class A with additional functions proposed in the paper-part 1.

For the BACS efficiency class $C$ variant (Figure 1), the following functional assumptions were adopted:

- DHW heating temperature control taking into account the water temperature measurement, water temperature settings as well as the selected operating mode with the time schedule;

- Electric vehicle charging station power control, taking into account time schedule and $\mathrm{PV}$ output voltage measurement (PV is the main energy source to supply charging station); PV output voltage affects efficiency of the charge process;

- Battery charging control with charging controller, taking into account the PV output voltage as well as time schedule;

- PV panel position control with drive controller, taking into account the PV panel output voltage and light intensity;

- Heating control, taking into account the selected operating mode, time schedule as well as indoor temperature measurements.

This variant of the BACS functional design for class $C$ ensures the implementation of the basic control functions for heating system in building and DHW temperature control, taking into account the information from the temperature sensors outside and inside the building. In addition, this control scenario takes into account basic time schedules in controlling the operation of heating systems, servicing electric vehicle charging stations as well as integrated energy storage. A basic system for controlling the position of PV 
panels is also implemented (with an external light intensity sensor) to increase their energy efficiency.

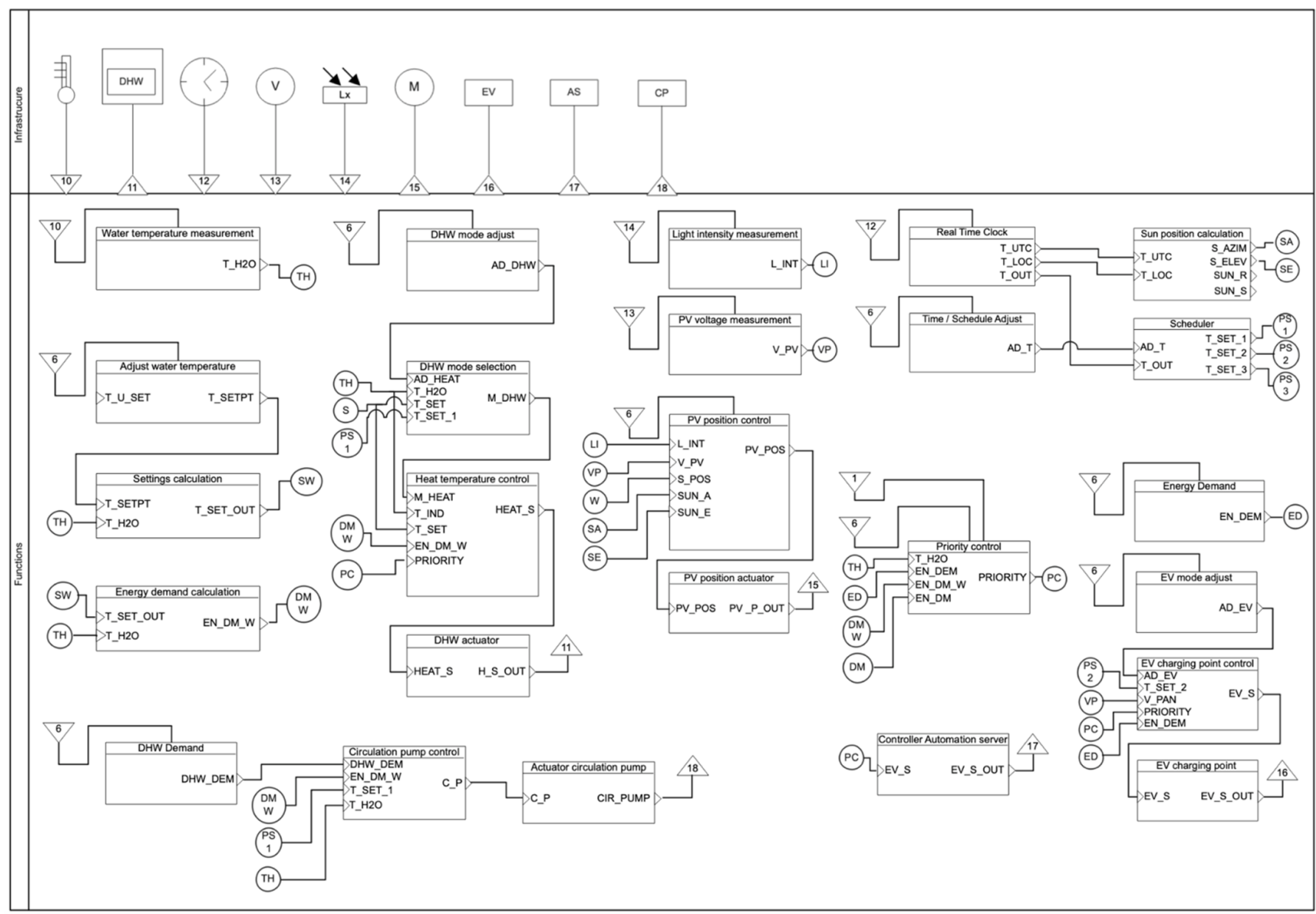

Figure 3. A functional diagram of control and energy management system for small prosumer installation organized according to the EN 15232 standard BACS efficiency class A with additional functions proposed in the paper-part 2.

For the BACS efficiency class A variant (Figures 2 and 3), the following functional assumptions were adopted:

- DHW installation control with variable heating time and supply depending on the demand as well as temperature management depending on the time schedule, priorities of control systems and the selected operating mode;

- Additional control of circulation pump for DHW system depending on DHW and energy demands as well as time schedule;

- Automatic EV charging station control depending on the demand, time schedule, selected operating mode, system priorities and the PV panels output voltage;

- Battery charging control with charging controller, taking into account the PV output voltage, time schedule as well as system priorities and energy demand;

- PV panel position control with drive controller, taking into account the PV panel output voltage, light intensity and data from weather station (rain detection, wind speed) with safety position as well as location and position coordinates of the Sun (azimuth, elevation);

- Heating control, taking into account the selected operating mode (global for building, individual for the rooms) with time schedule as well as indoor temperature measurements and depending on demand. 
This variant of the BACS functional design for class A ensures the implementation of advanced functions and algorithms of heating control in the building and DHW temperature regulation, taking into account both information from temperature sensors outside and inside as well as the presence/occupancy in the rooms and the level of demand for heat and electricity in the building. The control scenario also takes into account the advanced regulation for the circulation pump in the DHW system as well as advanced time schedules in controlling the operation of heating systems (including the operating mode of the heating system and energy demand), servicing electric vehicle charging stations and energy storage (taking into account the settings of the operating point and power supply priorities in the energy system). An advanced system for controlling the position of PV panels is also implemented, taking into account weather conditions, the intensity of outdoor light and the voltage level at the output of the panels. This advanced approach provides an additional increase of energy efficiency for PV panels. The automation system also includes monitoring and data acquisition functions for the automation server, which enables the implementation of advanced processing, analytics, and system data visualization functions.

\subsection{Evaluation of a Potential Impact of BACS on Building Energy Performance}

A potential impact on building energy performance resulting from the application of the BACS functions in accordance with the functional designs presented in the previous subsection, could be estimated considering BACS efficiency factors determined in the EN 15232 standard [6].

As mentioned in Section 2, the EN 15232 standard introduces four different BACS efficiency classes along with the lists of the BACS and TBM functions affecting building energy performance. However, this standard introduces a simplified BACS factor method for rough estimation of the impact of the BACS on thermal and electrical building energy performance related to the efficiency classes D, C, B and A defined in the standard. According to the EN 15232 standard, "the BACS factor method is specially appropriated to the early design stage of a building" with proposed functional design of the BACS and TBM to verify its usefulness in a specific application case [6,37]. The BACS efficiency factors are determined in the EN 15232 standard depending on building types (residential, non-residential) and the BACS efficiency classes. Since in this paper the author proposed functional designs for prosumer installation in residential houses and/or very small public or commercial buildings, the BACS efficiency factors for residential buildings have been considered in this evaluation, for given $C$ and A efficiency classes, respectively, to the designs described in the previous subsection.

The overall BACS efficiency factors for two kinds of energies-thermal and electricrelated to residential buildings are presented in Table 5.

Table 5. The overall BACS efficiency factors for residential buildings.

\begin{tabular}{ccc}
\hline $\begin{array}{c}\text { Residential Buildings } \\
\text { Single Family Houses } \\
\text { Apartment Block } \\
\text { Other Residential Buildings }\end{array}$ & \multicolumn{2}{c}{ BACS Efficiency Factors } \\
\hline BACS Efficiency Classes & Class C (Reference) & Class A \\
\hline Thermal energy & 1 & 0.81 \\
Electric energy & 1 & 0.92 \\
\hline
\end{tabular}

Moreover, to determine more detail information about possible energy savings due to BACS and TBM functions application, detailed BACS efficiency factors have been provided in the EN 15232 standard. They are related directly to several kinds of the subsystems and installations in buildings' infrastructures. In Table 6, some of them are presented related to systems and devices included in the set of BACS devices for a small prosumer installation (in residential buildings) discussed in Section 2. 
Table 6 . The selected detailed BACS efficiency factors for residential buildings.

\begin{tabular}{ccc}
\hline $\begin{array}{c}\text { Residential Buildings } \\
\text { Single Family Houses } \\
\text { Apartment Block } \\
\text { Other Residential Buildings }\end{array}$ & \multicolumn{2}{c}{ BACS Efficiency Factors } \\
\hline BACS Efficiency Classes & Class C (Reference) & Class A \\
\hline Heating energy & 1 & 0.81 \\
Cooling energy & not determined & not determined \\
DHW & 1 & 0.80 \\
Lighting * (non-residential) & 1 & $0.72-1$ \\
Auxiliary electric energy * (non-residential) & 1 & $0.72-0.96$
\end{tabular}

* BACS efficiency factors for electric energy for lighting as well as auxiliary energy (other electric devices in buildings) are determined only for non-residential buildings (according to the latest 2017 EN 15232 standard). The range of the factors' values presented in the Class A column depends on different kinds of non-residential buildings such as offices, hospitals, restaurants, educational buildings, etc. [6,22,33]

As seen in Table 6, the systems and devices of heating category with BACS advanced control functions offer potential $20 \%$ savings in thermal energy consumption for residential buildings. Although the factors for lighting systems and other electric devices in residential buildings are not directly determined in the EN 15232 standard, it is worth paying attention to possible significant energy savings in these categories for non-residential ones. The average level of potential savings is $20 \%$-similar thermal energy - and results of some of the research as well as the case studies discussed in Section 1 support this assumption $[17,21,22]$.

Therefore, additional control functions proposed by the author in Table 4 as well as services related to selected categories of devices in the SRI evaluation presented in Table 3 should be considered in the estimation of the additional BACS efficiency factors along with factors already determined within the EN 15232 standard. However, all these control functions and services used in functional designs proposed and described in Section 3.1 have not been implemented and verified yet. As it has been mentioned in Section 2.3, they should be considered as authors' proposal of possible new provisions in standards, technical guidelines, etc. By analyzing the solutions proposed in functional projects presented in Figures 1-3, it is possible to identify only potential areas of savings in the prosumer installation. For PV installation, the use of a system that follows the sun allows to increase the efficiency of PV panels and increase the production of electricity. In addition, the use of solar radiation and panel temperature sensors helps in effective alarming of darkening/obscuring or dangerous heating of the PV panel surface and dynamic control of their work. Another possible scenario is the use of a time schedule with additional dynamic detection of people presence (occupancy) in the rooms to heat the building. When the building is used, the heating system is turned on, but it stops working when there are no people in the building/rooms. A similar scenario is possible for other subsystems as well (lighting, HVAC, etc.) Such functions allow to save energy intended for the provision of thermal and lighting comfort in rooms and to reduce the overall building operating costs. An important element in the context of savings is also the accumulation/storage of the energy produced by the RES available in the prosumer microgrid. For a comprehensive PV installation, it is possible to control the charging of batteries installed in the building and then use the stored energy to power a specific device or group of devices (both DC and AC), so the prosumer does not have to use the energy supplied from the power grid. This option should be considered as a crucial element of the power supply system for the infrastructure of building automation systems-controllers, automation servers, smart sensors, etc.

It is expected that these potential areas for more efficient energy use and savings should provide energy efficiency improvements from a few to a dozen or so percent. These expectations are based on the results of several experiments and case studies carried out by the author in the last few years and presented in $[3,21,22,37]$. All these research and tests were performed to verify the provisions and guidelines of the EN 15232 standard, prior to the introduction of the SRI. In particular, in [37], Ożadowicz et al. present the results of 
measurements of electricity consumption for lighting and the HVAC system for various university classroom control strategies in the form of functional diagrams in accordance with the VDI 3813 standard.

Since new functional designs presented in this Section 3 need a series of tests, simulations as well as real results from case studies to be quantified, these activities are mentioned as future work in the Section 5-Conclusions. In this paper, the author focuses on a discussion of new opportunities and possibilities related to the original, hybrid approach in BACS control functions design with SRI and EN 15232 standard guidelines.

\section{Discussion}

Analysis of the BACS functional designs presented in the previous section indicates that symbiosis and integration of the EN 15232 standard and the SRI methodology guidelines provide additional benefits both in increasing the energy efficiency of buildings with local, prosumer microgrids and in ensuring a high level of smartness. Similar conclusions have been provided in $[9,20,28]$, some of the latest papers considering SRI methodology in the context of smart buildings and BACS designs. However, in this paper, the author notes some very significant shortcomings in the currently applicable EN 15232 ver. 2017 mentioned in Section 1. They concern the lack of guidelines and provisions relating to the categorization of control and monitoring functions for new devices and subsystems in buildings: RES, energy storage, smart meters or electric cars. At the same time, guidance on the category and level of functionality (similar to the BACS efficiency classes in the EN 15232 standard) for such functions is provided in the SRI estimation methodology shown in the report [10]. Therefore, in the author's opinion, the SRI assessment guidelines should be used in the future revision and modification of the EN 15232 standard, which should be supplemented with the categories of BACS and TBM functions for the aforementioned new elements of building infrastructure. It is crucial in the perspective of integrating buildings into the structures and mechanisms of energy management in local microgrids and smart grids with BEMS, DSM, DSR tools and techniques [2,3,40]. This approach is the base for a hybrid approach to the design and technical organization of field-level BACS networks proposed as one of the contributions of this paper.

Effectiveness of the symbiosis and integration discussed above depends on several factors, both positive and negative aspects related to the discussed documents, standards, and their provisions. These factors first of all depend on the precision and uniqueness of the standards' provisions and guidelines of the SRI assessment methodology as well as engineers' experience, features of specific application, availability of building automation devices, technologies, etc. Therefore, the author decided to group the factors as the strengths, weaknesses, opportunities and threats for the process of developing high standards in terms of the design of the BACS factions, their specifications and impact on building energy performance. These groups are presented in Table 7 in the form of the SWOT analysis. 
Table 7. Integration of the EN 15232 standard and SRI assessment methodology-SWOT analysis.

\begin{tabular}{|c|c|}
\hline Strengths & Weaknesses \\
\hline 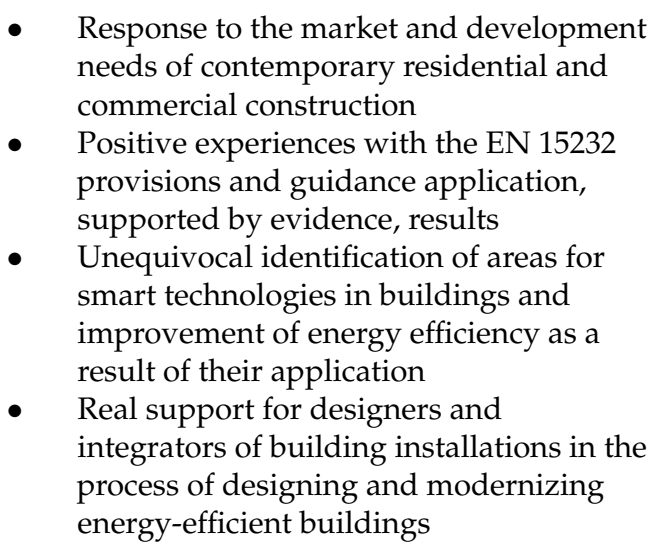 & $\begin{array}{l}\text { - Lack of clear, precise provisions for SRI } \\
\text { methodology (not defined, not quantified) } \\
\text { The SRI assessment methodology is still } \\
\text { under development } \\
\text { - } \quad \begin{array}{l}\text { Additional costs and time related to the } \\
\text { development of standards and norms }\end{array}\end{array}$ \\
\hline Opportunities & Threats \\
\hline 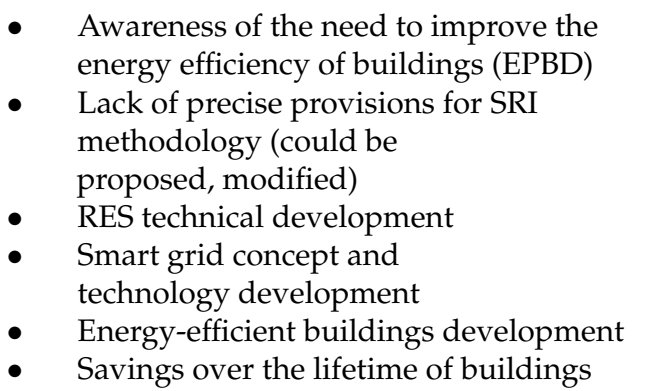 & $\begin{array}{l}\text { - Additional application costs for buildings } \\
\text { users and investors } \\
\text { The necessary long periods of discussion } \\
\text { on the provisions of the standards and } \\
\text { practical verification in case studies to } \\
\text { provide reliable quantitative results } \\
\text { Difficulties in the unification of } \\
\text { quantitative indicators of energy } \\
\text { efficiency improvement for various } \\
\text { climate zones in Europe and in the world }\end{array}$ \\
\hline
\end{tabular}

\section{Conclusions}

This paper proposes a novel hybrid approach to the design and technical organization of field-level BACS networks for new and retrofitted buildings, considering provisions of both the EN 15232 standard as well as the EPBD 2018 with the SRI assessment method. This approach is a real response to the growing share of RES and active energy management mechanisms in commercial and residential buildings, especially in terms of the development of prosumers' installations. Moreover, the methodology proposed in this paper addresses a normative gap in the selection of BACS functions dedicated to the operation of devices in prosumer microgrids (RES, energy storages, EV charging, etc.) and the evaluation of their impact on the energy efficiency of the building and local microgrid. The potential level of impact is discussed, with particular emphasis on the expected increase in the BACS impact on energy efficiency in the field of electricity in buildings, thanks to the inclusion of the new control functions of the infrastructure of prosumer microgrids proposed in the paper. This inclusion should be based on services proposed for assessment of the SRI and should be considered in future revision works related to the EN 15232 standard. Furthermore, in order to explain the way of BACS functional design, considering new control and monitoring functions for PV installation with prosumer microgrid energy management TBM functions, a set of control functions for PV systems within the prosumer installation has been proposed along with possible assignment to the BACS efficiency classes defined in the EN 15232. Examples of functional diagrams of control and energy management systems for small prosumer installations for different BACS efficiency classes have been proposed and discussed as well.

In future works, these BACS and TBM functions will be successively implemented within pilotage PV system installations to verify assumptions described in this paper as well as to collect qualitative and quantitative results supporting the new hybrid BACS designing approach proposed by the author. Different kinds of buildings and different PV technologies will be examined taking into account a variety of functional characteristics 
of buildings and applications of PV systems. For case studies, additional cost analyses should be performed to show a real savings level in relation to the investments needed. Furthermore, the concept of a hybrid approach application in local microgrids and virtual plants designs will be considered and developed as well.

Funding: This research has been funded by ERA-NET Smart Grid Plus SMARTGRIDPLUS-3/1/2019. Institutional Review Board Statement: Not applicable.

Informed Consent Statement: Not applicable.

Conflicts of Interest: The author declares no conflict of interest.

\section{References}

1. Wang, N.; Xu, W.; Xu, Z.; Shao, W. Peer-to-Peer Energy Trading among Microgrids with Multidimensional Willingness. Energies 2018, 11, 3312. [CrossRef]

2. Anvari-Moghaddam, A.; Rahimi-Kian, A.; Mirian, M.S.; Guerrero, J.M. A Multi-Agent Based Energy Management Solution for Integrated Buildings and Microgrid System. Appl. Energy 2017, 203, 41-56. [CrossRef]

3. Ożadowicz, A. A New Concept of Active Demand Side Management for Energy Efficient Prosumer Microgrids with Smart Building Technologies. Energies 2017, 10, 1771. [CrossRef]

4. EU. Directive 2010/31/EU of the European Parliament and of the Council of 19 May 2010 on the Energy Performance of Buildings (Recast). Off. J. Eur. Union 2010, 53, 13-35. [CrossRef]

5. European Parliament. Directive 2012/27/EU of the European Parliament and of the Council of 25 October 2012 on Energy Efficiency. Off. J. Eur. Union Dir. 2012, 55, 1-56. [CrossRef]

6. EN 15232; Energy Performance of Buildings-Impact of Building Automation, Controls and Building Management. European Committee for Standarization: Brussels, Belgium, 2017.

7. Grela, J.; Ozadowicz, A. Building Automation Planning and Design Tool Implementing EN 15232 BACS Efficiency Classes. In Proceedings of the 2016 IEEE 21st International Conference on Emerging Technologies and Factory Automation (ETFA), Berlin, Germany, 6-9 September 2016; pp. 1-4.

8. European Parliament. Directive (EU) 2018/844 of the European Parliament and of the Council on the Energy Performance of Buildings. Off. J. Eur. Union Dir. 2018.

9. Ramezani, B.; Silva, M.G.; da Simões, N. Application of Smart Readiness Indicator for Mediterranean Buildings in Retrofitting Actions. Energy Build. 2021, 249, 111173. [CrossRef]

10. Verbeke, S.; Aerts, D.; Reynders, G.; Ma, Y.; Waide, P. Final Report on the Technical Support To the Development of a Smart Readiness Indicator For Buidings; Office of the European Union: Brussels, Belgium, 2020; ISBN 978-92-76-19197-1.

11. BaaS Consortium Partners. Building as a Service. Final Report of the Project Funded by the European Community in the 7th Framework Programme ICT for Sustainable Growth. 2016. Available online: https://www.baas-project.eu/index.php/public/ menunews.html (accessed on 28 December 2021).

12. Froiz-Míguez, I.; Fernández-Caramés, T.; Fraga-Lamas, P.; Castedo, L. Design, Implementation and Practical Evaluation of an IoT Home Automation System for Fog Computing Applications Based on MQTT and ZigBee-WiFi Sensor Nodes. Sensors 2018, 18, 2660. [CrossRef]

13. Delsing, J. Local Cloud Internet of Things Automation: Technology and Business Model Features of Distributed Internet of Things Automation Solutions. IEEE Ind. Electron. Mag. 2017, 11, 8-21. [CrossRef]

14. Board of Directors of the Corporation Project Haystack-Documentation. Available online: https://project-haystack.org/doc/ docHaystack/index (accessed on 28 December 2021).

15. Ozadowicz, A.; Grela, J.; Wisniewski, L.; Smok, K. Application of the Internet of Things (IoT) Technology in Consumer ElectronicsCase Study. In Proceedings of the 2018 IEEE 23th International Conference on Emerging Technologies and Factory Automation (ETFA), Turin, Italy, 4-7 September 2018; pp. 1037-1042.

16. Beccali, M.; Bonomolo, M.; Galatioto, A.; Ippolito, M.G.; Zizzo, G. A Laboratory Setup for the Evaluation of the Effects of BACS and TBM Systems on Lighting. In Proceedings of the 2015 International Conference on Renewable Energy Research and Applications (ICRERA), Palermo, Italy, 22-25 November 2015; Volume 5, pp. 1388-1393.

17. Beccali, M.; Bonomolo, M.; Ippolito, M.G.; Lo Brano, V.; Zizzo, G. Experimental Validation of the BAC Factor Method for Lighting Systems. In Proceedings of the 2017 IEEE International Conference on Environment and Electrical Engineering and 2017 IEEE Industrial and Commercial Power Systems Europe (EEEIC/I\&CPS Europe), Milan, Italy, 6-9 June 2017; pp. 1-5.

18. Felius, L.C.; Hamdy, M.; Hrynyszyn, B.D.; Dessen, F. The Impact of Building Automation Control Systems as Retrofitting Measures on the Energy Efficiency of a Typical Norwegian Single-Family House. IOP Conf. Ser. Earth Environ. Sci. 2020, 410, 012054. [CrossRef]

19. Felius, L.C.; Hamdy, M.; Dessen, F.; Hrynyszyn, B.D. Upgrading the Smartness of Retrofitting Packages towards Energy-Efficient Residential Buildings in Cold Climate Countries: Two Case Studies. Buildings 2020, 10, 200. [CrossRef] 
20. Engvang, J.A.; Jradi, M. Auditing and Design Evaluation of Building Automation and Control Systems Based on Eu.Bac System Audit-Danish Case Study. Energy Built Environ. 2021, 2, 34-44. [CrossRef]

21. Kaminska, A.; Ożadowicz, A. Lighting Control Including Daylight and Energy Efficiency Improvements Analysis. Energies 2018, 11, 2166. [CrossRef]

22. Ożadowicz, A.; Grela, J. Energy Saving in the Street Lighting Control System-A New Approach Based on the EN-15232 Standard. Energy Effic. 2017, 10, 563-576. [CrossRef]

23. al Dakheel, J.; del Pero, C.; Aste, N.; Leonforte, F. Smart Buildings Features and Key Performance Indicators: A Review. Sustain. Cities Soc. 2020, 61, 102328. [CrossRef]

24. Fokaides, P.A.; Panteli, C.; Panayidou, A. How Are the Smart Readiness Indicators Expected to Affect the Energy Performance of Buildings: First Evidence and Perspectives. Sustainability 2020, 12, 9496. [CrossRef]

25. Märzinger, T.; Österreicher, D. Supporting the Smart Readiness Indicator-A Methodology to Integrate A Quantitative Assessment of the Load Shifting Potential of Smart Buildings. Energies 2019, 12, 1955. [CrossRef]

26. Märzinger, T.; Österreicher, D. Extending the Application of the Smart Readiness Indicator-A Methodology for the Quantitative Assessment of the Load Shifting Potential of Smart Districts. Energies 2020, 13, 3507. [CrossRef]

27. Schönenberger, P. Eu. Bac System. Energy Build. 2015, 100, 16-19. [CrossRef]

28. Engelsgaard, S.; Alexandersen, E.K.; Dallaire, J.; Jradi, M. IBACSA: An Interactive Tool for Building Automation and Control Systems Auditing and Smartness Evaluation. Build. Environ. 2020, 184, 107240. [CrossRef]

29. VDI 3813. Gebäudeautomation (GA)_Raumautomation; Verein Deutscher Ingenieure e.V.: Dusseldorf, Germany, 2011.

30. Mancini, F.; Lo Basso, G.; de Santoli, L. Energy Use in Residential Buildings: Impact of Building Automation Control Systems on Energy Performance and Flexibility. Energies 2019, 12, 2896. [CrossRef]

31. Cockroft, J.; Cowie, A.; Samuel, A.; Strachan, P. Potential Energy Savings Achievable by Zoned Control of Individual Rooms in UK Housing Compared to Standard Central Heating Controls. Energy Build. 2017, 136, 1-11. [CrossRef]

32. Kräuchi, P.; Dahinden, C.; Jurt, D.; Wouters, V.; Menti, U.-P.; Steiger, O. Electricity Consumption of Building Automation. Energy Procedia 2017, 122, 295-300. [CrossRef]

33. Kwasnowski, P.; Fedorczak-Cisak, M. Methodology of Specification and Design of Public Utility Buildings to Reach the Maximum Energy Performance According to EPBD and EN 15232: 2012 Standard. Tech. Trans. Archit. 2014, 7-A, 133-138.

34. Chadderton, D.V. Building Services Engineering; Routledge: London, UK, 2013; ISBN 9780203121320.

35. Ploennigs, J.; Lehmann, M.; Wollschlaeger, B.; Mai, T.L.; Kabitzsch, K. Multi-Objective Device Selection Approach for ComponentBased Automation Systems. In Proceedings of the 2014 IEEE Emerging Technology and Factory Automation (ETFA), Barcelona, Spain, 16-19 September 2014; pp. 1-8.

36. Lehmann, M.; Mai, T.L.; Wollschlaeger, B.; Kabitzsch, K. Design Approach for Component-Based Automation Systems Using Exact Cover. In Proceedings of the 2014 IEEE Emerging Technology and Factory Automation (ETFA), Barcelona, Spain, 16-19 September 2014; pp. 1-8.

37. Ozadowicz, A.; Grela, J. Impact of Building Automation Control Systems on Energy Efficiency-University Building Case Study. In Proceedings of the 2017 22nd IEEE International Conference on Emerging Technologies and Factory Automation (ETFA), Limassol, Cyprus, 12-15 September 2017; pp. 1-8.

38. Technical University Dresden AUTERAS-Smart Building Design Tool. Available online: https://www.auteras.de (accessed on 31 December 2021).

39. ABB Company An Integrated Building Automation Solution Environment. Available online: https://new.abb.com/news/detail/ 11238/an-integrated-building-automation-solution-environment (accessed on 31 December 2021).

40. Ghazvini, M.A.F.; Soares, J.; Abrishambaf, O.; Castro, R.; Vale, Z. Demand Response Implementation in Smart Households. Energy Build. 2017, 143, 129-148. [CrossRef] 